\title{
Antimicrobial Activities of New Indole Derivatives Containing 1,2,4-Triazole, 1,3,4-Thiadiazole and Carbothioamide
}

\author{
1,2,4-Triazol, 1,3,4-Tiyadiazol ve Karbotiyoamit İçeren Yeni İndol \\ Türevlerinin Antimikrobiyal Aktiviteleri
}

\author{
(D) Hanif SHIRINZADEH ${ }^{1 *}$, (D) Sibel SÜZEN², (D) Nurten ALTANLAR ${ }^{3}$, (D) Andrew D. WESTWELL ${ }^{4}$ \\ 'Erzincan University, Faculty of Pharmacy, Department of Pharmaceutical Chemistry, Erzincan, Turkey \\ ${ }^{2}$ Ankara University, Faculty of Pharmacy, Department of Pharmaceutical Chemistry, Ankara, Turkey \\ ${ }^{3}$ Ankara University, Faculty of Pharmacy, Department of Pharmaceutical Microbiology, Ankara, Turkey \\ ${ }^{4}$ Cardiff University, Faculty of Pharmacy, Department of Pharmaceutical Chemistry, Cardiff, United Kingdom
}

\begin{abstract}
Objectives: In new antimicrobial drug development studies, indole and its derivatives create an important class of compounds. In addition, azoles and their derivatives were recognized to be associated with a variety of biologic activities such as antibacterial and antifungal. In this study antimicrobial activities of some indole derivatives mainly substituted with 1,2,4-triazole, 1,3,4-thiadiazole and hydrazinecarbothioamide were investigated to evaluate their efficacy.

Materials and Methods: The efficacy of new compounds was evaluated using 2-fold serial dilutions against Staphylococcus aureus, MRSA, Escherichia coli, Bacillus subtilis, Candida albicans, and Candida krusei.

Results: The MIC was determined for test compounds and for the reference standards sultamicillin, ampicillin, fluconazole, and ciprofloxacin.

Conclusion: The compounds possessed a broad spectrum of activity having MIC values of $3.125-50 \mu \mathrm{g} / \mathrm{mL}$ against the tested microorganisms. This study provides valuable evidence that the indole-triazole derivative compound $3 \mathrm{~d}$ holds significant promise as a novel antibacterial and antifungal lead compound.
\end{abstract}

Key words: Indole, 1, 2, 4-triazole, 1, 3, 4-thiadiazole, MRSA, C. krusei

Öz

Amaç: Yeni antibakteriyel ilaç geliştirilme çalışmalarında indol ve türevleri önemli bir bileşik sınıfı oluşturmaktadır. Ayrıca azoller ve türevlerinin antibakteriyel ve antifungal gibi biyolojik aktivite gösterdikleri dikkat çekmektedir. Bu çalışmada 1,2,4-triazol, 1,3,4-tiyadiazol ve hidrazinkarbotiyoamid ile sübstitüe edilmiş indol türevi yeni bileșiklerin, antimikrobiyal etkinlikleri araştırılarak değerlendirilmiștir.

Gereç ve Yöntemler: Yeni bileşiklerin antimikrobiyal etkinlikleri, 2-kat seri dilüsyon yöntemi kullanılarak, Staphylococcus aureus, MRSA, Escherichia coli, Bacillus subtilis, Candida albicans ve Candida krusei'ye karşı araștırılarak değerlendirilmiştir.

Bulgular: Yeni sentezlenen bileşiklerin MiK, sultamisilin, ampisilin, flukonazol ve siprofloksasin gibi standart referans bileşiklere karşı belirlenmiştir. Sonuç: Bileşikler test edilen mikroorganizmalara karşı 3.125-50 $\mu \mathrm{g} / \mathrm{mL}$ gibi geniş spektrum aralığında MiK değerleri göstermişlerdir. Bu çalışmada değerli veriler elde edilmiş ve indol-triazol türevi olan 3d bileşiği antibakteriyel ve antifungal lider bileşik olarak ileri çalıșmalar için gelecek vaad etmektedir.

Anahtar kelimeler: İndol, 1, 2, 4-triazol, 1, 3, 4-tiyadiazol, MRSA, C. krusei

*Correspondence: E-mail: hanif.shirinzade@gmail.com, Phone: +904462245344 ORCID-ID: orcid.org/0000-0001-9663-9199

Received: 03.08.2017, Accepted: 19.10.2017

-Turk J Pharm Sci, Published by Galenos Publishing House. 


\section{INTRODUCTION}

Antimicrobial resistance is often used as a definition for drug resistance, which occurs when microorganisms such as bacteria, viruses, fungi, and parasites withstand a drug that was intended to cure the infection., ${ }^{1,2}$ Multidrug-resistant strains of Methicillin-resistant Staphylococcus aureus (MRSA) cause some serious infections such as pneumonia, endocarditis, and skin and soft tissue infections within intensive care units., ${ }^{3,4}$ Recent studies confirmed that indole derivatives have promising antimicrobial activity against various microorganisms including MRSA. ${ }^{5}$ Studies showed that one of the main contributors to Staphylococcus aureus antibiotic resistance is the NorA efflux pump. ${ }^{6,7}$ NorA is able to export a variety of structurally unrelated drugs, such as fluoroquinolones, ethidium bromide, cetrimide, benzalkonium chloride, tetraphenylphosphonium bromide, and acriflavine. ${ }^{8}$ Indoles are one of the reported classes of NorA inhibitors, ${ }^{9}$ for example, 5-nitro-2-phenylindole, which characterizes a promising lead structure able to produce a 4-fold increase in S. aureus susceptibility to ciprofloxacin..$^{10}$ Tertbutyl (2-(3-hydroxyureido)-2-(1H-indol-3-yl)ethyl) carbamate, which is not toxic to human cells, was also found to be an active indolic NorA inhibitor."1

Azole-containing compounds such as fluconazole, ketoconazole, and itraconazole are the most widely used antifungal agents in the clinic.12,13 Despite all the claims, many studies have demonstrated the ineffectiveness of fluconazole against Candida krusei, ${ }^{14,15}$ which has been recognized as a potentially multidrug-resistant fungal pathogen. ${ }^{16}$ Consequently, it is essential to develop new active compounds against fungal pathogens including $C$. krusei. Multidrug-resistant infection strains are diseases of emerging healthcare concern and have demanded the attention of researchers. Synthesis and antifungal activity of indole-linked triazole derivatives ${ }^{17}$ showed that almost all indole derivatives showed excellent antifungal activities against Candida albicans and $C$. krusei with low minimum inhibitory concentration (MIC) values. ${ }^{18}$ Antimicrobial activity studies of some 1,2,4-triazole and 1,3,4-thiadiazole derivatives indicated good antimicrobial activity. ${ }^{19,20}$ In addition, it is well known that imidazoles and triazoles (azoles) make up the largest group of agents against mycosis infections. ${ }^{21}$ Indole derivatives were found to be particularly effective and suitable for further developments in antimicrobial drug development studies. ${ }^{22}$

This study is part of an ongoing project in the search for novel antimicrobial drug candidates, especially against MRSA and C. krusei. New indole derivatives substituted with triazole, thiadiazole, and carbothioamide were tested against $S$. aureus, MRSA, Escherichia coli, Bacillus subtilis, C. albicans and C. krusei using the 2-fold serial dilution technique. The MIC was determined for the test compounds and for the reference standards sultamicillin, ampicillin, fluconazole, and ciprofloxacin.

\section{MATERIALS AND METHODS}

\section{Chemistry}

The synthesis and spectroscopic characterization of 31 indole derivatives (Table 1) were published in our earlier study. ${ }^{23}$ The reaction of indole 3-acetylhydrazine with isothiocyanates in ethanol under reflux gave the corresponding hydrazinecarbothioamides (1a-h). Treatment of $1 \mathrm{a}-\mathrm{h}$ under acidic conditions with full region chemical control gives the corresponding 2-aminothiadiazoles (2a-h). Conversely, treatment of 1a-h under basic conditions (aq. $\mathrm{NaOH}$ ) with heating produced 3-thiotriazoles (3a-h). Triazoles (3a-h) could be further alkylated under basic conditions to yield substituted triazoles (4a-g).

\section{Microbiology}

Antibacterial and antifungal activity tests were conducted against standard strains. The American Type Culture Collection (ATCC) strains of the microorganisms used in this study were obtained from the culture collection of the Refik Saydam Health Institution of Health Ministry, Ankara, and maintained at the Microbiology Department of the Faculty of Pharmacy of Ankara University. Mueller-Hinton broth (MHB) (Difco), Mueller-Hinton agar (MHA) (Oxoid), Sabouraud Dextrose agar (SDA) (Difco), and Sabouraud Dextrose broth (SDB) (Difco), were used for growing and diluting the microorganism suspensions. The following reference strains were used for testing antimicrobial activity: Gram-positive bacteria: S. aureus ATCC 25923, MRSA ATCC 43300, B. subtilis ATCC 6633. Gram-negative bacteria: E. coli ATCC 25922, Yeast: C. albicans ATCC 10231 and C. krusei ATCC 6258.

\section{Antibacterial and antifungal activity assay}

The bacterial strains were maintained on MHA medium for 24 $\mathrm{h}$ at $37^{\circ} \mathrm{C}$ and fungi were maintained on SDA for $48 \mathrm{~h}$ at $25^{\circ} \mathrm{C}$. Overnight cultures were prepared by inoculating approximately $2 \mathrm{~mL}$ MHB with 2-3 colonies of each organism taken from MHA. Inocula were prepared by diluting overnight cultures into $0.9 \%$ sterile saline solution until the visible turbidity was equal to 0.5 Mcfarland standard having approximately $10^{8} \mathrm{CFU} /$ $\mathrm{mL}$ for bacteria and $10^{7} \mathrm{CFU} / \mathrm{mL}$ for yeasts. The tube dilution technique was used for the determination of the MICs. ${ }^{24,25}$ Indole derivatives were investigated to evaluate their efficacy against multi-drug-resistant microbial infections by using the 2-fold serial dilution technique against S. aureus, MRSA, E. coli, B. subtilis, C. albicans and C. krusei.

The synthesized compounds and standards were dissolved in $12.5 \%$ DMSO at concentrations of $200 \mu \mathrm{g} / \mathrm{mL}$. Further dilutions of the compounds and standard drugs in the test medium were prepared at the following quantities of 400, 200, 100, 50, 25 , $12.5,6.25,3.12,1.56$ and $0.78 \mu \mathrm{g} / \mathrm{mL}$ concentrations with $\mathrm{MHB}$ and SDB. A set of tubes containing only inoculated broth was used as controls.

After incubation for $24 \mathrm{~h}$ at $37^{\circ} \mathrm{C}$ for the antibacterial assay and for $48 \mathrm{~h}$ at $25^{\circ} \mathrm{C}$ for the antifungal assay, the last tube with no growth of microorganism and/or yeast was recorded to represent the MIC (expressed in $\mu \mathrm{g} / \mathrm{mL}$ ). The MIC was determined for test compounds and for the reference standards sultamicillin, ampicillin, fluconazole, and ciprofloxacin. Every experiment in the antibacterial and antifungal assays was performed in duplicate.

There was no need for ethics committee approval because the study was conducted in vitro. 


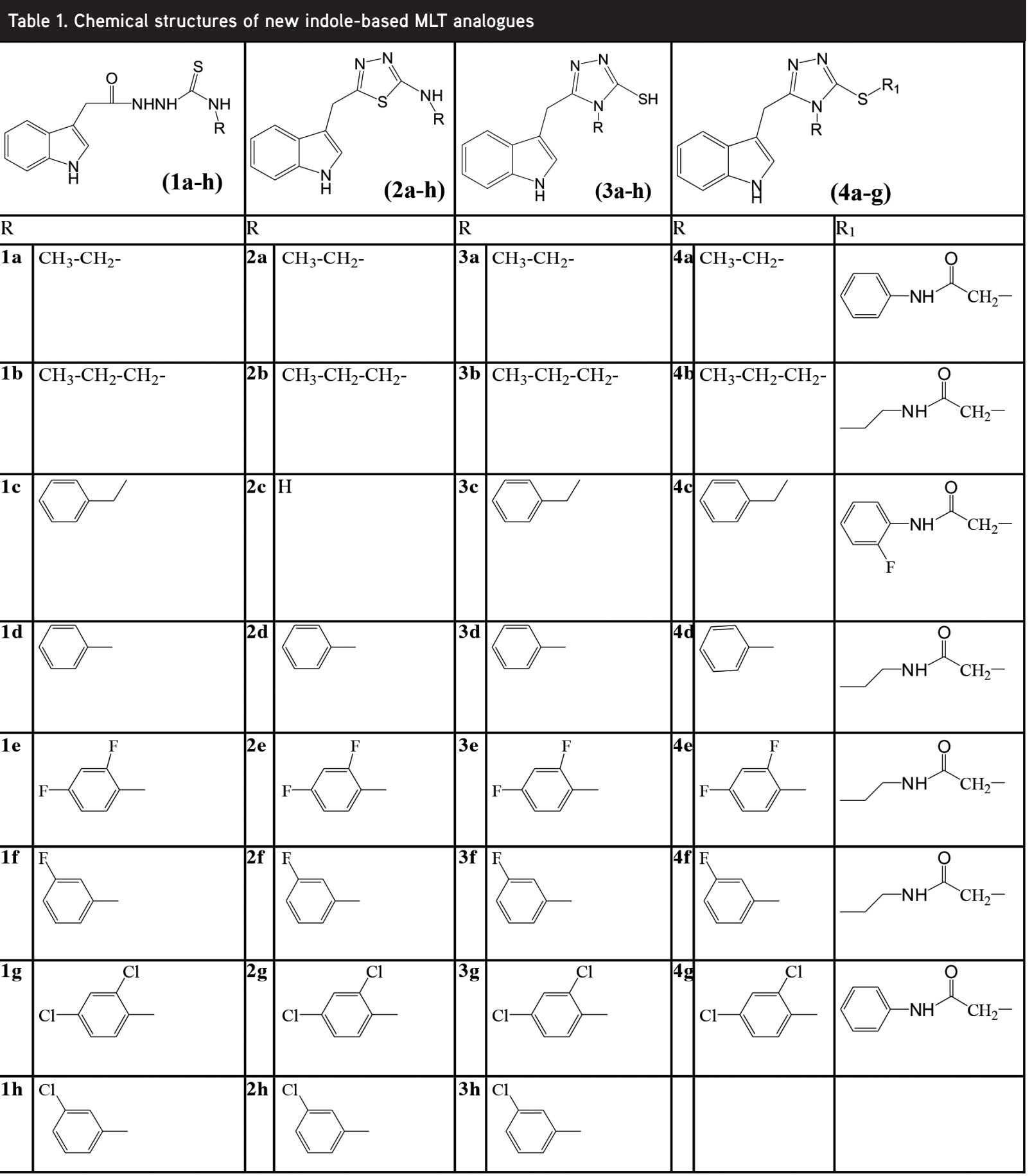

MLT: Melatonin

\section{RESULTS AND DISCUSSION}

Antimicrobial activity was investigated by finding the MICs of the indole derivatives against S. aureus, MRSA, E. coli, B. subtilis, C. albicans and C. krusei strains and comparing with ampicillin, sultamicillin, ciproflaxacin and fluconazole as standard drugs. The MIC values of the compounds and standard drugs are given in Table 2. The MIC values were within the range of 3.125-50 $\mathrm{\mu g} / \mathrm{mL}$. Most of the compounds showed significant antibacterial activity against $S$. aureus, MRSA, E. coli, and B. subtilis. In addition, the compounds demonstrated a good level of antifungal activity, particularly against C. krusei, even more effective than the standard drug fluconazole.

The antibacterial activity of all tested compounds demonstrated acceptable antibacterial effects. Compounds 1c, 1h, 3h, and $4 \mathrm{C}$ showed moderate activity against $S$. aureus compared with ampicillin, sultamicillin, ciprofloxacin; the most effective compounds were $2 \mathrm{~h}$ (indole-thiadiazole) and $3 \mathrm{~d}$ (indoletriazole) with an MIC value of $6.25 \mu \mathrm{g} / \mathrm{mL}$ (Figure 1a).

Figure $1 b$ shows the antibacterial effects of the tested compounds against MRSA strains. The activities of compounds 
Table 2. MIC values $(\mu \mathrm{g} / \mathrm{mL})$ of tested indole derivatives

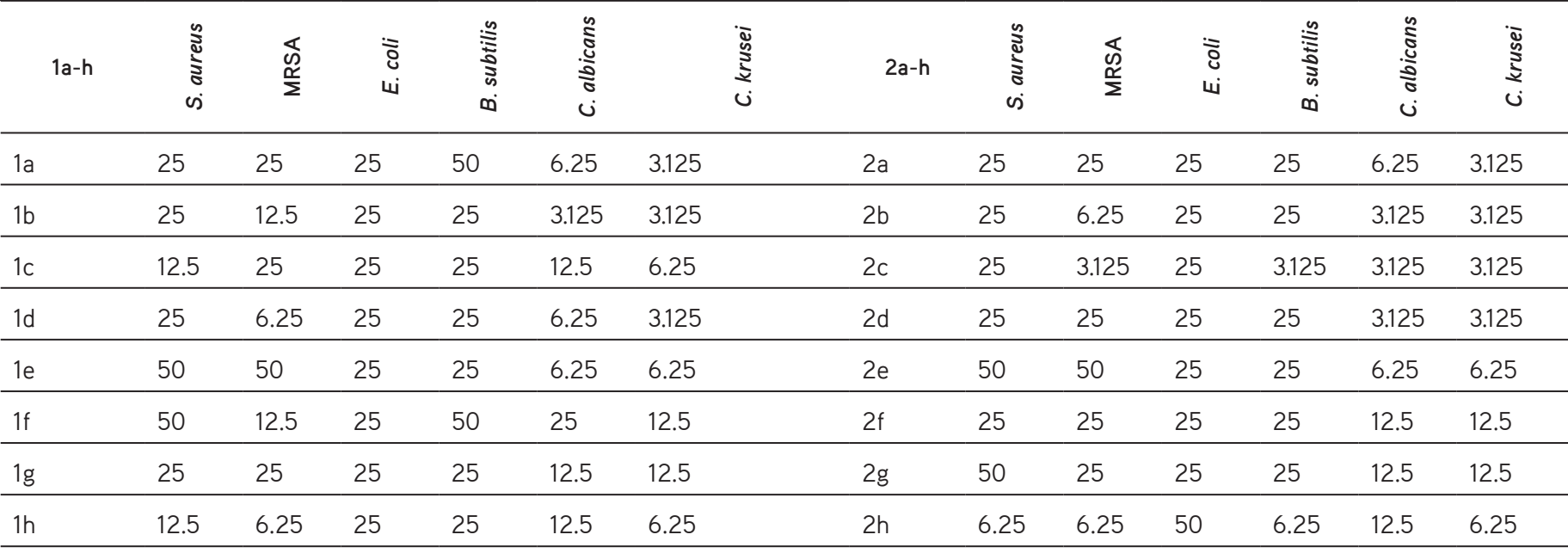

\begin{tabular}{|c|c|c|c|c|c|c|c|c|c|c|c|c|c|}
\hline 3a-h & $\begin{array}{l}\text { š } \\
\text { ș } \\
\text { c) }\end{array}$ & $\begin{array}{l}\frac{\alpha}{0} \\
\frac{\alpha}{\Sigma}\end{array}$ & $\begin{array}{l}\bar{c} \\
\text { uे }\end{array}$ & 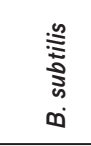 & 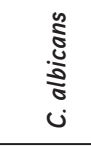 & ù & 4a-g & $\begin{array}{l}\text { ș } \\
\text { క̦ } \\
\text { cे }\end{array}$ & $\begin{array}{l}\mathbb{1} \\
0 \\
\frac{1}{\Sigma} \\
\end{array}$ & $\begin{array}{l}\overline{\mathrm{z}} \\
\text { u }\end{array}$ & 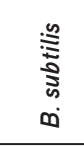 & 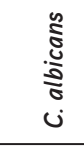 & 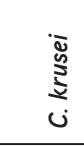 \\
\hline $3 a$ & 50 & 25 & 25 & 25 & 12.5 & 3.125 & $4 a$ & 25 & 25 & 25 & 12.5 & 12.5 & 3.125 \\
\hline $3 b$ & 25 & 12.5 & 25 & 25 & 3.125 & 3.125 & $4 b$ & 50 & 50 & 25 & 50 & 12.5 & 6.25 \\
\hline $3 c$ & 25 & 50 & 25 & 3.125 & 3.125 & 3.125 & $4 c$ & 12.5 & 25 & 25 & 25 & 12.5 & 6.25 \\
\hline $3 d$ & 6.25 & 3.125 & 50 & 25 & 3.125 & 3.125 & $4 d$ & 50 & 50 & 25 & 50 & 12.5 & 3.125 \\
\hline $3 e$ & 50 & 25 & 25 & 25 & 6.25 & 3.125 & $4 e$ & 50 & 50 & 25 & 50 & 6.25 & 3.125 \\
\hline $3 f$ & 25 & 25 & 25 & 25 & 12.5 & 12.5 & $4 f$ & 50 & 50 & 25 & 50 & 12.5 & 3.125 \\
\hline $3 g$ & 25 & 12.5 & 25 & 50 & 6.25 & 3.125 & $4 \mathrm{~g}$ & 25 & 25 & 25 & 25 & 12.5 & 3.125 \\
\hline $3 \mathrm{~h}$ & 12.5 & 6.25 & 25 & 12.5 & 6.25 & 3.125 & - & - & - & - & - & - & - \\
\hline
\end{tabular}

Reference standards
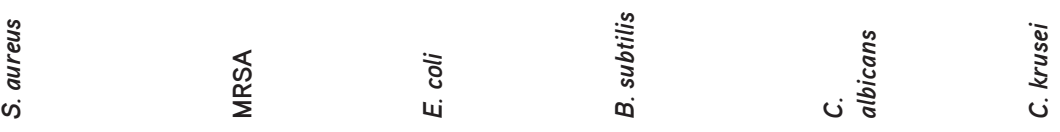

\begin{tabular}{lllllll}
\hline Sultamicillin & 0.39 & 25 & 25 & 0.78 & - & - \\
\hline Ampicillin & 0.78 & 50 & 50 & 50 & - & - \\
\hline Fluconazole & - & - & - & - & 1.56 & 64 \\
\hline Ciprofloxacin & 0.78 & 6.25 & 0.19 & 0.09 & - & - \\
\hline
\end{tabular}

$1 d, 1 h, 2 b, 2 h$, and $3 h$ were found to be at the same level as ciprofloxacin, and compounds 2c (indole-thiadiazole) and $3 \mathrm{~d}$ (indole-triazole) demonstrated excellent activity against MRSA, being more effective than ciprofloxacin. The other tested compounds were found to have the same activity value or were more active than ampicillin and sultamicillin.

None of the tested indole derivatives were more active than ciprofloxacin, which has an MIC value of $0.09 \mu \mathrm{g} / \mathrm{mL}$ against $E$. coli. However, most of the synthesized compounds demonstrated the same or lower MIC values compared with ampicillin and sultamicillin (Figure 2a). Finally, the effects of the tested indole derivatives against $B$. subtilis strains (Figure $2 b$ ) showed that the most effective compounds were $2 c$ (indole-thiadiazole) and $3 c$ (indole-triazole) with an MIC value of $3.125 \mu \mathrm{g} / \mathrm{mL}$. Although the tested compounds were not as active as ciprofloxacin and sultamicillin, they were much more active than ampicillin.

The MIC values of the tested indole derivatives indicated that nearly all them showed excellent antifungal activities against C. krusei and moderate activities against $C$. albicans compared with the standard drug fluconazole. Figure 3a shows the MIC values of the indole compounds against $C$. albicans compared with fluconazole. The most effective compounds were $1 b, 2 b-d$, and $3 \mathrm{~b}-\mathrm{d}$, with MIC values of $3.125 \mu \mathrm{g} / \mathrm{mL}$. Although the activity results against $C$. albicans were not very satisfactory, the results of antifungal activity against $C$. krusei strains were quite promising. All the tested compounds were found several times more effective than fluconazole. As seen in Figure $3 b$, most of the effective compounds $1 \mathrm{a}, 1 \mathrm{~b}, 1 \mathrm{~d} / 2 \mathrm{a}-\mathrm{d} / 3 \mathrm{a}-\mathrm{d}$, 3h, and $4 \mathrm{a}, 4 \mathrm{~d}-\mathrm{g}$ 
$\mu \mathrm{g} / \mathrm{mL}$

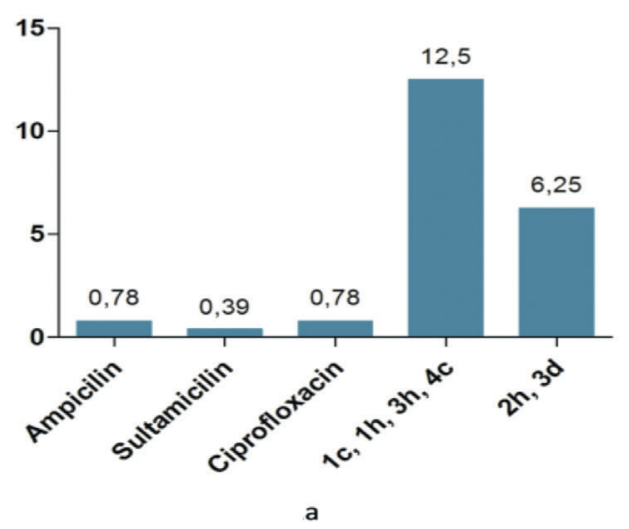

$\mu \mathrm{g} / \mathrm{mL}$

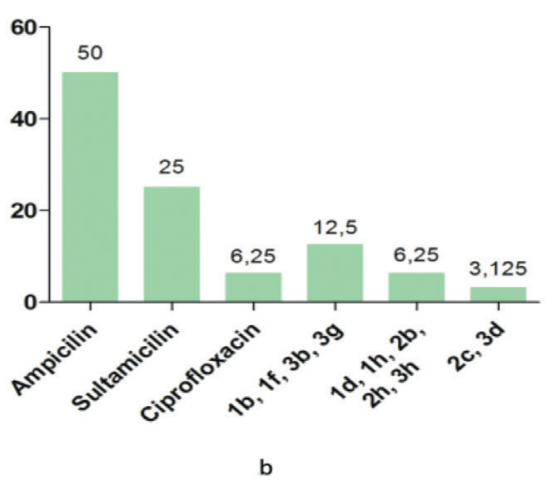

Figure 1. a) The MIC value of synthesized compounds against $S$. aureus compared with ampicillin, sultamicillin, ciprofloxacin. b) The MIC value of synthesized compounds against MRSA compared with ampicillin, sultamicillin, and ciprofloxacin

had MIC values of $3.125 \mu \mathrm{g} / \mathrm{mL}$, whereas fluconazole has an MIC value of $64 \mu \mathrm{g} / \mathrm{mL}$. The results were in accordance with those found by $\mathrm{Na}, 2010 .^{17}$ The most potent antifungal activity against C. krusei was obtained with halogenated indole derivatives.

\section{CONCLUSIONS}

According to the activity results, all of synthesized compounds demonstrated significant antibacterial and antifungal effects, and the antifungal effects of compounds 3a-h are promising for development into new, more effective lead compounds against C. krusei. Roughly $17 \%$ of Candida isolates exhibit resistance against azoles, and most probably, the extensive use of fluconazole is the main reason for this resistance. C. krusei is one of the species that shows actual resistance to fluconazole..$^{16,26}$ Therefore, the search for new and more effective anti-fungal agents against $C$. krusei seems ever more important. ${ }^{27}$ Azole compounds prevent the synthesis of ergosterol by inhibiting the cytochrome P-450-dependent enzyme lanosterol $14 \alpha$-demethylase. Triazoles have a broad range of applications in the treatment of fungal infections because of their good affinity for fungal cytochrome P-450 enzymes. ${ }^{28}$ It is reasonable to assume that the synthesized indole-triazole derivatives ( $3 a-$ $h, 4 a-g)$ have the same mechanism of action. $\mu \mathrm{g} / \mathrm{mL}$

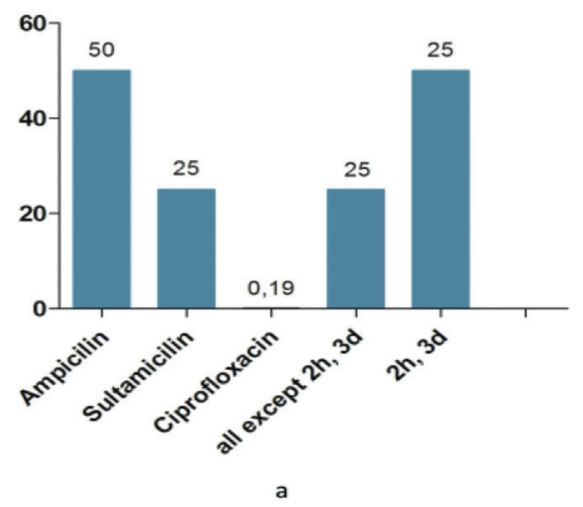

$\mu \mathrm{g} / \mathrm{mL}$

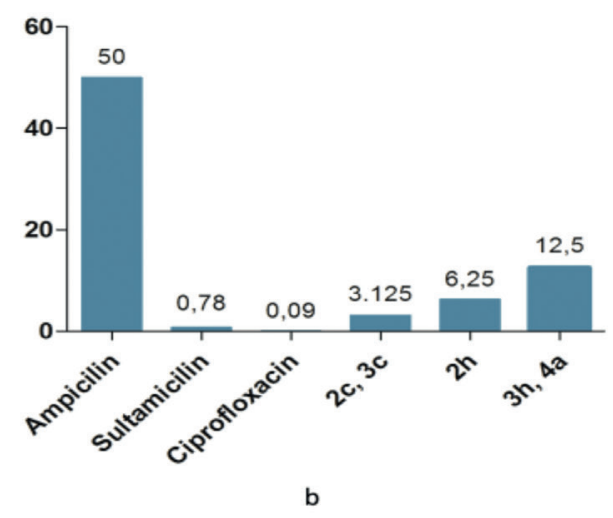

Figure 2. a) The MIC value of synthesized compounds against $E$. coli compared with ampicillin, sultamicillin, ciprofloxacin. b) The MIC value of synthesized compounds against B. subtilis compared with ampicillin, sultamicillin, ciprofloxacin

Compounds 2c (indole-thiadiazole) and 3d (indole-triazole) demonstrated excellent activity against MRSA at a much higher level than ciprofloxacin. It was observed that compounds $1 \mathrm{~h}, 2 \mathrm{~h}$ and $3 \mathrm{~h}$ had MIC values of $6.25 \mu \mathrm{g} / \mathrm{mL}$, which is the same as for ciprofloxacin. All these compounds have a $m$-chlorophenyl group as a substituent. This shows that both the indole ring and the side chains are important for activity. Singh stated that chloro substituents for triazolylindole derivatives were beneficial as well as hydroxy and methoxy substitution for activity. ${ }^{29}$

Most of the tested indole derivatives were found to be highly active against $C$. krusei. Between the tested indoles, the most active compounds were found in the indole-triazole group, followed by the indole-thiadiazole group. These results suggest that the tested indole derivatives are eligible for development as candidates, especially compound 3d, which is a promising lead compound mainly against MRSA and C. krusei. However, further research needs to be performed to determine the specific mode of action and approve indole derivatives as antimicrobial agents.

The common use of antifungal molecules combined with insufficient treatment are responsible for promoting these microorganisms' resistance to drugs used in treatment. The antibacterial and antifungal activity results were thought to 


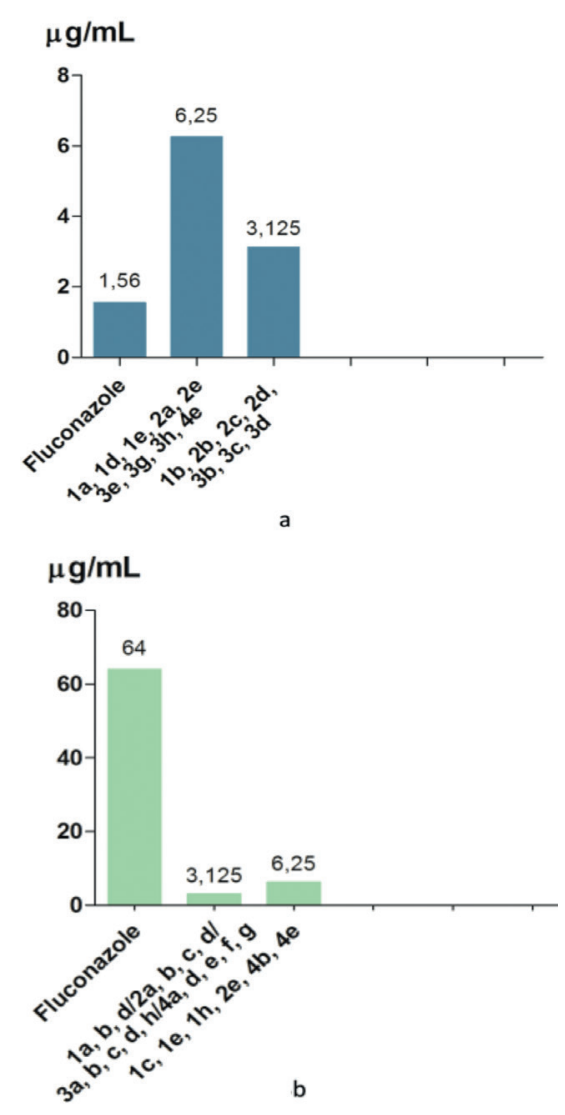

Figure 3. a) The MIC value of synthesized compounds against $C$. albicans compared with fluconazole. b) The MIC value of synthesized compounds against $C$. krusei compared with fluconazole

be exerted through a target because the introduction of the substituent groups on the indole caused differences in the activity. Therefore, modifications of these compounds should continue to be investigated.

\section{ACKNOWLEDGEMENTS}

The chemical synthesis part of this work was supported by the Scientific and Technological Research Council of Turkey (TUBITAK) Research and Development Grant 112S599.

Conflict of Interest: No conflict of interest was declared by the authors.

\section{REFERENCES}

1. Cerniglia CE, Pineiro SA, Kotarski SF. An update discussion on the current assessment of the safety of veterinary antimicrobial drug residues in food with regard to their impact on the human intestinal microbiome. Drug Test Anal. 2016;8:539-548.

2. Hahn AW, Jain R, Spach DH. New Approaches to antibiotic use and review of recently approved antimicrobial agents. Med Clin North Am. 2016;100:911-926.

3. Liu C, Bayer A, Cosgrove SE, Daum RS, Fridkin SK, Gorwitz RJ, Kaplan SL, Karchmer AW, Levine DP, Murray BE, J Rybak M, Talan DA, Chambers HF. Clinical practice guidelines by the infectious diseases society of
America for the treatment of methicillin-resistant Staphylococcus aureus infections in adults and children. Clin Infect Dis. 2011;52:18-55.

4. Kaku N, Morinaga $Y$, Takeda K, Kosai K, Uno N, Hasegawa $H$, Miyazaki T, Izumikawa K, Mukae H, Yanagihara K. Antimicrobial and immunomodulatory effects of tedizolid against methicillin-resistant Staphylococcus aureus in a murine model of hematogenous pulmonary infection. Int J Med Microbiol. 2016;306:421-428.

5. Al-Qawasmeh RA, Huesca M, Nedunuri V, Peralta R, Wright J, Lee $Y$, Young A. Potent antimicrobial activity of 3-(4,5-diaryl-1H-imidazol-2yl)-1H-indole derivatives against methicillin-resistant Staphylococcus aureus. Bioorg Med Chem Lett. 2010;20:3518-3520.

6. Lepri S, Buonerba F, Goracci L, Velilla I, Ruzziconi R, Schindler BD, Seo SM, Kaatz, GW, Cruciani G. Indole based weapons to fight antibiotic resistance: a structure-activity relationship study. J Med Chem. 2016;59:867-891.

7. Costa SS, Viveiros M, Amaral L, Couto I. Multidrug Efflux Pumps in Staphylococcus aureus: an Update. Open Microbiol J. 2013;7:59-71.

8. Deng X, Sun F, Ji Q, Liang H, Missiakas D, Lan L, He C. Expression of multidrug resistance efflux pump gene NorA is iron responsive in Staphylococcus aureus. J Bacteriol. 2012;194:1753-1762.

9. Markham PN, Westhaus E, Klyachko K, Johnson ME, Neyfakh AA. Multiple novel inhibitors of the NorA multidrug transporter of Staphylococcus aureus. Antimicrob Agents Chemother. 1999;43:2404-2408.

10. Ambrus JI, Kelso MJ, Bremner JB, Ball AR, Casadei G, Lewis K. Structure-activity relationships of 2 -aryl-1h-indole inhibitors of the nora efflux pump in Staphylococcus aureus. Bioorg Med Chem Lett. 2008;18:4294-4297.

11. Hequet A, Burchak ON, Jeanty M, Guinchard X, Le Pihive E, Maigre L, Bouhours P, Schneider D, Maurin M, Paris JM, Denis JN, Jolivalt C. 1-(1H-Indol-3-yl)ethanamine derivatives as potent Staphylococcus aureus NorA efflux pump Inhibitors. Chem Med Chem. 2014;9:1534-1545.

12. Fridkin SK, Jarvis WR. Epidemiology of nosocomial fungal infections. Clin Microbiol Rev. 1996;9:499-511.

13. Che X, Sheng C, Wang W, Cao Y, Xu Y, Ji H, Dong G, Miao Z, Yao J, Zhang W. New azoles with potent antifungal activity: design, synthesis and molecular docking. Eur J Med Chem. 2009;44:4218-4226.

14. Samaranayake YH, Samaranayake LP. Candida krusei: biology, epidemiology, pathogenicity and clinical manifestations of an emerging pathogen. J Med Microbiol. 1994;41:295-310.

15. Deorukhkar SC, Saini S. Echinocandin susceptibility profile of fluconazole resistant Candida species isolated from blood stream infections. Infect Disord Drug Targets. 2016;16:63-68.

16. Pfaller MA, Diekema DJ, Gibbs DL, Newell VA, Nagy E, Dobiasova S, Rinaldi M, Barton R, Veselov A. Global Antifungal Surveillance Group. Candida krusei, a Multidrug-Resistant Opportunistic Fungal Pathogen: Geographic and Temporal Trends from the ARTEMIS DISK Antifungal Surveillance Program, 2001 to 2005. J Clin Microbiol. 2008;46:515-521.

17. Na YM. Synthesis and activity of novel indole linked triazole derivatives as antifungal agents. Bull Korean Chem Soc. 2010;31:3467-3470.

18. Ryu CK, Lee JY, Park RE, Ma MY, Nho JH. Synthesis and antifungal activity of 1H-indole-4,7-diones. Bioorg Med Chem Lett. 2007;17:127-131.

19. Chen $\mathrm{H}, \mathrm{Li} Z$, Han Y. Synthesis and fungicidal activity against rhizoctoniasolani of 2-alkyl (alkylthio)-5-pyrazolyl-1,3,4-oxadiazoles (thiadiazoles). J Agric Food Chem. 2000;48:5312-5315. 
20. Ahmed S, Zayed MF, El-Messery SM, Al-Agamy MH, Abdel-Rahman HM. Design, synthesis, antimicrobial evaluation and molecular modeling study of 1,2,4-Triazole-based 4-Thiazolidinones. Molecules. 2016:21.

21. Odds FC, Brown AJ, Gow NA. Antifungal agents: mechanisms of action. Trends Microbiol. 2003;11:272-279.

22. Varvaresou A, Tsantili-Kakoulidou A, Siatra-Papastaikoudi T, Tiligada E. Synthesis and biological evaluation of indole containing derivatives of thiosemicarbazide and their cyclic 1,2,4-triazole and 1,3,4- thiadiazole analogs. Arzneimittelforschung. 2000;50:48-54.

23. Shirinzadeh $H$, Ince $E$, Westwell $A D$, Gurer-Orhan $H$, Suzen S. Novel indole-based melatonin analogues substituted with triazole, thiadiazole and carbothioamides: studies on their antioxidant, chemopreventive and cytotoxic activities. J Enzyme Inhib Med Chem. 2016;31:1312-1321.

24. Clinical and Laboratory Institute. Methods for dilution antimicrobial susceptibility tests for bacteria that grow aerobically, Approved
Standard. in: CLSI Publication M07-A10, Twelfth ed. CLSI; Wayne, PA, USA; 2009.

25. Clinical and Laboratory Standards Institute (CLSI), Reference method for broth dilution antifungal susceptbility testing of yeasts; Approved Standart. Third ed. CLSI document M27-A3. Wayne, PA, USA; 2008.

26. Kanafani ZA, Perfect JR. Antimicrobial resistance: to antifungal agents: mechanisms and clinical impact. Clin Infect Dis. 2008;46:120-128.

27. Gill K, Kumar S, Xess I, Dey S. Novel synthetic anti-fungal tripeptide effective against Candida krusei. Indian J Med Microbiol. 2015;33:110-116.

28. Asami T, Mizutani M, Shimada Y, Goda H, Kitahata N, Sekimata K, Han SY, Fujioka S, Takatsuto S, Sakata K, Yoshida S. Triadimefon, a fungicidal triazole-type P450 inhibitor, induces brassinosteroid deficiency-like phenotypes in plants and binds to DWF4 protein in the brassinosteroid biosynthesis pathway. Biochem J. 2003;369:71-76.

29. Singh I. Synthesis and evaluation of some newly triazolylindole derivatives for antifungal activity. Int Res J Pharm. 2014;5:891-895. 